\title{
University Company Government Interaction: FAPEMIG as Propeller Agent of the Scientific-Technological Development in Minas Gerais, Brazil
}

Jamil Ramsi Farkat Diogenes, Rodolfo Fernando Carvalho Vieira, Nathaline Oliveira Falcão, Fernanda Cristina Barbosa Pereira Queiroz, Jamerson Viegas Queiroz UFRN, Natal/RN, Brasil

\begin{abstract}
This article aims to present the main indicators for Science, Technology, and Innovation (ST\&I) generated by the Fundação de Amparo à Pesquisa do Estado de Minas Gerais (FAPEMIG) in four years (2008-2011). The methodology used was a case study, with documentary research, held in the annual reports of activities of the foundation. The results showed that all indicators analyzed in aggregate form, evolved gradually. It is concluded that the FAPEMIG comes complying with their mission to induce and encourage research and scientific and technological innovation for the development of the State of Minas Gerais in the southeast region, maintaining the recognition as one of the main agents of development inductors ST\&I in Brazil.
\end{abstract}

Keywords: development, innovation, university

\section{Introduction}

The constant promotion of science, technology and innovation (ST\&I) allows a nation to achieve sustainable socio-economic development. Federal Law no 10.973/04 of Brazil "establishes incentives for innovation and scientific and technological research in the productive environment, with a view to training and within the reach of technological autonomy and industrial development of the country" encouraging the construction of specialized environments and cooperative innovation (Brazil, 2004).

In Brazil, through agencies, foundations, and funds, to finance actions linked to ST\&I happen to contribute to the development of the country. The foundations of ST\&I are most representative in Brazil, which are linked to the federal government. These, according to some state laws are sponsored with $1 \%$ of all taxes collected, ensuring their activities.

According to Ministério da Educação (MEC) (2012), “The foundations are institutions created with the purpose of supporting the projects of research, teaching, and extension of institutional, scientific, and

Jamil Ramsi Farkat Diogenes, MSc Student in Production Engineering, Production Engineering Department, UFRN.

Rodolfo Fernando Carvalho Vieira, Graduate Student in Production Engineering, Production Engineering Department, UFRN.

Nathaline Oliveira Falcão, Graduate Student in Production Engineering, Production Engineering Department, UFRN.

Fernanda Cristina Barbosa Pereira Queiroz, Ph.D. in Production Engineering, Professor of Production Engineering Department, UFRN.

Jamerson Viegas Queiroz, Ph.D. in Production Engineering, Professor of Production Engineering Department, UFRN.

Correspondence concerning this article should be addressed to Jamil Ramsi Farkat Diogenes, Production Engineering Department, UFRN, Brasil. E-mail: farkatt@gmail.com. 
technological development, the interests of federal institutions of higher education (IFES) and research institutions also" (p. 1), thus being able to contribute faithfully to the achievement of national innovation systems in a nation.

In numbers, the Conselho Nacional das Fundações de Amparo à Pesquisa (CONFAP) (2012) Brazilian national territory confirms that there are 24 state foundations, these three have higher representativeness for funding, in large financial flows, ST\&I. The Fundação de Amparo à Pesquisa do Estado de São Paulo (FAPESP), Fundação de Amparo à Pesquisa do Estado do Rio de Janeiro (FAPERJ), and Fundação de Amparo à Pesquisa do Estado de Minas Gerais (FAPEMIG) make up this trio.

In this context, choosing the FAPEMIG as a case to be studied, the research aims to present the main indicators for ST\&I generated by the foundation.

For both the organization of the present study begins with this introduction, followed by section two "Innovation and Competitiveness", section three "National Innovation System", and section four "Cooperation Between: University, Company and Government”. The sections two, three, and four contains concepts relevant to this research. In continuity, section five presents "The Research Method", which is the methodological procedure used to develop this research. Section six describes the "Studying Object", recounting a brief history of the foundation. Lastly, section seven show the "Results" followed by "Conclusions" in section eight.

\section{Innovation and Competitiveness}

Zaltman, Duncan, and Holbek (1973) defined innovation as an idea, practice, or a material that is perceived as a new and relevant application. Thus, Dosi (1998) confirmed that search involves innovation, experimentation, discovery, development, and adoption of new products, new production processes, and new organizational settings.

The ability to generate technological innovation is proportional to the economic development of a nation. The economist Joseph Schumpeter is one of the first proponents of this binding between a country's development and its ability to innovate. The original idea of Schumpeter guides the thought of a broad group of economists, called "neo-schumpeterian", is that technological innovation is the engine of economic development.

In the current environment, marked by competitiveness, innovation is seen as a way to overcome competition and achieve competitive advantage. From innovation strategies, opportunities can be converted into new ideas and put into widespread practical use (Tidd, Bessant, \& Pavitt, 2001).

According to Rogers (2003), the "most innovations are created by scientific research, although they often result from the interaction between scientific methods and practical problems" (p. 140). Therefore, the "innovation is no longer perceived necessarily as a linear process, but as a result of the complex interaction of various actors and institutions that constitute a system of agents strongly interdependent” (OECD, 1999, p. 11).

Tidd et al. (2001) evidenced during the 1990s, through their researches in industrial organizations and English services, organizations can use innovation to differentiate their products and services, which are typically twice as profitable as the others.

Understanding innovation as an economic power at the end of 2004, the Brazilian Federal Government sanctioned the innovation law (Law No. 10.973). Barbosa (2006) explained that this law encourages the promotion of ST\&I in the industry, seeking the improvement of technological skills and Brazilian industrial 
development. This law covers important aspects as cooperation between science and technology institutions and enterprises, the division of laboratories, incubation of small enterprises in public research institutes, services of research and development for businesses for businesses, the establishment of technology transfer offices (TTOs), as well as the participation of researchers in economic gains generated by the inventions and innovative sponsorship (Maculan, 2005).

\section{National Innovation System}

Freeman (1995) set the national innovation system as a set of institutions, actors, and mechanisms in a country contribute to the creation, advancement, and dissemination of technological innovations. Simonini (2010) included the universities, companies, research institutions, and other associations as actors, which in turn relating to the market and the current financial system, converges to the formation of the innovation system.

OECD (1999) presented a pattern of co-operation in national innovation systems, in which we highlight the following: cooperation between university and industry; geographical proximity; innovation depends on cooperation; knowledge-intensive services; informal cooperation and trust; and finally it is rising that the innovation system has different patterns of cooperation.

There is a diversity of systems because of their stage of development in each country. According to Albuquerque (1999), this diversity could be perceived by the characteristics of the configuration of each system, such as the specifics of innovative companies, the interaction between firms and universities or research institutions, and even the various forms of financing of research and innovation.

\section{Cooperation Between University, Company, and Government}

The cooperation between university, government, and company appears at the beginning of the 21st century as an instrument to promote technological development, dissemination, and uptake of innovations. According to Queiroz (2007), "The ability to innovate depends on the conduct of scientific research and requires human resources capable of generating and transmitting new knowledge” (p. 3).

In this context, the role of universities has been acquiring greater relevance, since they still present themselves as the main locus in the trainer of new knowledge (Rapini, 2007).

In this scenario, it is crucial to the existence of an academic institution that plays a role in the innovation system and in the social, technological, and economic development of the country. The university aims to be an enterprising demand creation of complex structures within it to house companies of technological base, promoting cooperation between researchers and local businessmen.

The effects caused by these changes drive the debate about what is the appropriate role that universities should play in matters related to technology and knowledge transfer.

Etzkowitz and Leydesdorff (2000) believed that, in response to this new environment, universities should take ownership of the "third mission". In addition to contributing to the development of the country with the formation of high-level human resources and research, third mission would seek to incorporate the mission to contribute more directly to economic development through cooperative and collaborative initiatives with the productive sector in order to achieve greater applicability for the knowledge produced.

Within this context, the entrepreneurial university differentiates itself from others with regard to three 
basic characteristics: support for entrepreneurial activities; the existence of mechanisms for interface, such as the offices of technology transfer; and a significant number of employees capable of creating companies (Dzisah \& Etzkowitz, 2009).

\section{Research Method}

As to the nature, this research is classified as applied. In relation to the objectives, this research is descriptive and exploratory. As for the approach, this research is classified as qualitative using the case study method.

The survey took place in two stages. The first corresponded to bibliographical research, in which it was necessary to review the existing literature and define the scope of the search, creating products such as the theoretical and research basis identification. The second was the documentary analysis phase, in which it was necessary to verify the common indicators for ST\&I, in the reports consulted, making possible the formation of the results.

The documentary analysis phase, covered the annual activity reports in the period from 2008 to 2011, accessed via the foundation's institutional website.

\section{Studying Object}

The FAPEMIG is a foundation of the State Government, linked to the Secretary of State for science, technology, and higher education, was created by Law Delegated $n^{\circ} 10$, from August of 1985, which has the mission: "induce and encourage research and scientific and technological innovation for the development of the State of Minas Gerais”, seeking "be recognized as the principal agent inductor scientific, technological development and innovation in the State of Minas Gerais” (FAPEMIG, 2011, p. 18).

Their performance is linked to the financing of scientific and technological research projects, in encouraging the training of human resources for science and technology, the establishment of scientific and technological research groups, in promoting the productive sector and integrative research institutions and development, supporting the organization of scientific and technological events, to carry out exchanges between Brazilian and foreign researchers in the routing and guidance of patenting and commercialization of innovative products and processes.

The beneficiaries of the actions performed by FAPEMIG consist of Minas Gerais-based institutions or researchers that they maintain bond that falls into one of the following categories: (1) scientific, technological entities, and Innovation-STEIs; (2) direct and indirect administration corporations of the government of the State of Minas Gerais, aimed at the development of ST\&I or other related scientific and technological activities; (3) associative entities, not-for-profit whose objectives are geared towards the promotion of scientific and technological development; (4) private companies, enterprise companies, incubators, technology parks and the like, serving notices and specific programs; and (5) individual researchers to keep some ties to STEIs, the activities developed by FAPEMIG are ensured by the State Constitution, which determines the allocation of $1 \%$ of the current budget revenues of the State for the promotion of ST\&I.

\section{Results}

In the quadrennium, the State Treasury provided USD 499 million, which added to external funds obtained, totaled USD 589 million invested in actions to promote the ST\&I as shown in Table 1. 
Table 1

\section{Kept Financial Resources}

\begin{tabular}{|c|c|c|c|c|}
\hline Year & $\begin{array}{l}\text { State treasure } \\
\text { (US\$ millions) }\end{array}$ & $\begin{array}{l}\text { Own and external resources } \\
\text { (US\$ millions) }\end{array}$ & Total (US\$ millions) & Growing (\%) \\
\hline 2008 & 110 & 13 & 123 & \\
\hline 2009 & 102 & 14 & 116 & -5.6 \\
\hline 2010 & 132 & 29 & 161 & 38.7 \\
\hline 2011 & 155 & 34 & 189 & 17.3 \\
\hline Total & 499 & 90 & 589 & \\
\hline
\end{tabular}

As the targeting of funds raised in the quadrennium, the research projects, adding their natures (universal, induced, special, endogovernamental, and structuring) achieved major transfers, followed by investment in human resource training and scholarships, administrative costs, promotion of scientific and technical studies events and dissemination actions. Table 2 details the allocation of those resources.

Table 2

Percentual Execution of the Financial Resources

\begin{tabular}{llcrrr}
\hline & Item & $2008(\%)$ & $2009(\%)$ & $2010(\%)$ & $2011(\%)$ \\
\hline 01 & Research projects_Universal & 23.9 & 24.3 & 17.5 & 19.5 \\
02 & Research projects_Inducted & 16.0 & 20.1 & 29.3 & 27.3 \\
03 & Scholarship and HR formation & 23.9 & 24.3 & 17.0 & 17.8 \\
04 & Scientific events & 2.4 & 2.0 & 2.2 & 2.0 \\
05 & Special projects, endogovernamental, and structural & 29.3 & 24.3 & 29.0 & 28.6 \\
06 & Other activities (technical studies and disclosure) & 1.2 & 1.0 & 1.0 & 1.0 \\
07 & Administrative expenses & 3.3 & 4.0 & 4.0 & 3.8 \\
Total & & 100 & 100 & 100 & 100 \\
\hline
\end{tabular}

As for the number of research projects included in the universal demand (independent-inducing themes), gradual growth in submission of these during the quadrennium, and even noting a reduction in the hiring of the projects in the year 2009, the remaining year's recovery was reaching maximum hiring 750 projects in 2011. These numbers are detailed in Table 3.

Table 3

Universal Research Projects Submitted and Hired

\begin{tabular}{llccc}
\hline Universale edital & Submitted quantity & Submitted growing (\%) & Hired quantity & Hired quantity (\%) \\
\hline 2008 & 1,436 & & 737 & \\
2009 & 1,546 & 7.6 & 703 & -4.6 \\
2010 & 1,799 & 16.3 & 720 & 2.4 \\
2011 & 1,866 & 3.7 & 750 & 4.1 \\
Total & 6,647 & 2,910 & \\
\hline
\end{tabular}

As the number of research projects included in the induced demand (with induction of subjects by state organs), the growth of the submissions of the other years from the year of 2009 was significant, as shown in Table 4. The data from 2008 and the quantities contracted for other years were not disclosed in the reports consulted. 
As the training of researchers in the quadrennium to FAPEMIG offered 5,811 shares the scientific initiation within the school through the "Scientific Initiation Scholarships Jr.—BIC Jr.”, 15,077 dimensions to scientific initiation within the undergraduate program "Institutional Program for Scientific Initiation Scholarships-PIBIC”, 3,379 units in mastering, 2,315 in doctorate, 1,143 in post-doctorate, 128 at 542 and a visiting scholar program on technological development, totaling 22,640 quotas directed the training of researchers. The distribution of these shares and the percentage growth rates compared to the previous year are detailed in Table 5.

Table 4

Submitting of Inducted Research Projects

\begin{tabular}{lll}
\hline Inducted edital & Submitted quantity & Growing (\%) \\
\hline 2009 & 1,610 & \\
2010 & 4,143 & 157.3 \\
2011 & 3,173 & -23.4 \\
Total & 8,926 & \\
\hline
\end{tabular}

Table 5

Shares of Financial Assistance for Training of Researchers

\begin{tabular}{lrrrrrrrr}
\hline & 2008 & 2009 & Growing (\%) & 2010 & Growing (\%) & 2011 & Growing (\%) & Total \\
\hline Bic Jr. & 819 & 1,133 & 38.3 & 1,273 & 12.3 & 1,383 & 8.6 & 5,881 \\
PIBIC & 2,510 & 2,944 & 17.2 & 3,064 & 4.0 & 3,495 & 14.0 & 15,077 \\
Mastering & 608 & 645 & 6.0 & 675 & 4.6 & 776 & 14.9 & 3,379 \\
Doctorate & 429 & 436 & 1.6 & 453 & 3.9 & 544 & 20.0 & 2,315 \\
Post-doctorate & 347 & 288 & -17 & 222 & 22.9 & 64 & -71.1 & 1,143 \\
Researcher visitor & 30 & 18 & -40 & 26 & 44.4 & 28 & 7.69 & 128 \\
Technological development & 93 & 125 & 34.41 & 112 & 10.4 & 100 & -10.7 & 542 \\
Total & 4,836 & 5,589 & & 5,825 & & 6,390 & & 28,465 \\
\hline
\end{tabular}

As the number of higher education institutions benefited from mining shares made available the scientific initiation programs, PIBIC program directed graduation contemplated more institutions that the BIC Jr. program which is targeted to high school. Already the quotas directed the graduate (stricto-senso), the master of most institutions that encompassed the doctorate as details in Table 6.

Table 6

Institutions Benefited by Financial Aid Quotas

\begin{tabular}{llllllll}
\hline Benefited institutions & 2008 & 2009 & Growing (\%) & 2010 & Growing (\%) & 2011 & Growing (\%) \\
\hline Bic Jr. & 30 & 35 & 16.6 & 42 & 20.0 & 43 & 2.3 \\
PIBIC & 60 & 65 & 8.3 & 71 & 9.2 & 76 & 7.0 \\
Mastering & 32 & 34 & 6.2 & 35 & 2.9 & 35 & 0.0 \\
Doctorate & 13 & 16 & 23.0 & 17 & 6.2 & 18 & 5.8 \\
\hline
\end{tabular}

As for the support of scientific events in the quadrennium, the foundation has promoted 1,016 events, and provided participation in 3,420 events, 1,210 collectively, 1,145 individually in international events, and 1,065 individually in Brazilian events. Table 7 details these numbers. 
Table 7

Support the Organization of and Participation in Scientific Events

\begin{tabular}{lccccccccc}
\hline $\begin{array}{l}\text { Organization } \\
\text { participation in events }\end{array}$ & and & 2008 & 2009 & Growing (\%) & 2010 & Growing (\%) & 2011 & Growing (\%) & Total \\
\hline Organization & 234 & 236 & 0.8 & 238 & 0.8 & 308 & 29.4 & 1,016 \\
Group participation & 246 & 287 & 16.6 & 337 & 17.4 & 340 & 0.8 & 1,210 \\
Exterior individual part & 291 & 230 & -20.9 & 303 & 31.7 & 321 & 5.9 & 1,145 \\
Individual Brazil part & 269 & 231 & -14.1 & 260 & 12.5 & 305 & 17.3 & 1,065 \\
\hline
\end{tabular}

As for the evaluation of projects undertaken in the quadrennium $(5,504), 57.41 \%$ evaluated projects were recommended, 36.35\% condicioned (needs improvement), and 6.23\% rejected. Points out that in the year 2008 the project evaluation Committee was not yet established, what justifies the absence of data in that year. The numbers of reviews are detailed in Table 8.

Table 8

Evaluation of Projects

\begin{tabular}{lcccl}
\hline Year & Recommended & Condicioned & Rejected & Total \\
\hline 2009 & $341(23.2 \%)$ & $1,015(69.1 \%)$ & $113(7.7 \%)$ & $1,469(100 \%)$ \\
2010 & $1,540(75.3 \%)$ & $434(21.2 \%)$ & $71(3.5 \%)$ & $2,045(100 \%)$ \\
2011 & $1,279(64.3 \%)$ & $552(27.7 \%)$ & $159(8.0 \%)$ & $1,990(100 \%)$ \\
Total & $3,160(57.41 \%)$ & $2,001(36.35 \%)$ & $343(6.23 \%)$ & $5,504(100 \%)$ \\
\hline
\end{tabular}

In the quadrennium, 40,224 scientific products were developed, 18.30\% of these are articles published in magazine, 40.58\% Congress presentations, 2.36\% book chapters, 0.49\% published books, $1.09 \%$ electronic publications, $1.19 \%$ newspaper publications of dissemination, 18.02\% summaries published, 8.27\% works published in annals of events, 2.95\% doctoral theses and 6.75\% master dissertations. These numbers are detailed in Table 9.

Table 9

Scientific Products Generated in Finished Projects

\begin{tabular}{|c|c|c|c|c|c|c|c|c|}
\hline Products & 2008 & 2009 & $\begin{array}{l}\text { Growing } \\
(\%)\end{array}$ & 2010 & $\begin{array}{l}\text { Growing } \\
(\%)\end{array}$ & 2011 & $\begin{array}{l}\text { Growing } \\
(\%)\end{array}$ & Total \\
\hline Articles published in magazines & 875 & 2,453 & 180.3 & 2,144 & -12.6 & 1,890 & -11.8 & 7,362 \\
\hline Congress presentations & 1,747 & 5,436 & 211.1 & 4,620 & -15.0 & 4,520 & -2.1 & 16,323 \\
\hline Books' chapters & 87 & 314 & 260.9 & 270 & -14.0 & 280 & 3.7 & 951 \\
\hline Published books & 12 & 60 & 400.0 & 61 & 1.6 & 63 & 3.2 & 196 \\
\hline Electronic publications & 61 & 172 & 181.9 & 88 & -48.8 & 156 & 77.2 & 477 \\
\hline Publications in disclosure newspapers & 69 & 124 & 79.7 & 136 & 9.6 & 111 & -18.3 & 440 \\
\hline Published abstracts & 675 & 2,467 & 265.4 & 2,119 & -14.1 & 1,985 & -6.3 & 7,246 \\
\hline Works in events annals & 327 & 1,017 & 211.0 & 1,024 & 0.7 & 960 & -6.2 & 3,328 \\
\hline Doctorate theses & 137 & 408 & 197.8 & 361 & -11.5 & 281 & -22.1 & 1,187 \\
\hline Mastering dissertations & 320 & 897 & 180.3 & 793 & -11.5 & 704 & -11.2 & 2,714 \\
\hline Total & 4,310 & 13,348 & & 11,616 & & 10,950 & & 40,224 \\
\hline
\end{tabular}


Table 10

Intellectual Property Protections

\begin{tabular}{lllllll}
\hline \multirow{2}{*}{ Year } & \multirow{2}{*}{ Trade marks } & \multicolumn{2}{l}{ National patents } & \multicolumn{2}{c}{ Patentes internacionais } & \multirow{2}{*}{ Computer programs } \\
\cline { 2 - 6 } & & Institutional & Independent & Institutional & Independent & \\
\hline 2008 & 7 & 17 & 4 & 6 & 0 & 3 \\
2009 & 20 & 36 & 2 & 5 & 0 & 9 \\
2010 & 13 & 38 & 1 & 19 & 0 & 8 \\
2011 & 10 & 32 & 9 & 6 & 1 & 21 \\
Total & 50 & 123 & 16 & 36 & 1 & 41 \\
\hline
\end{tabular}

As intellectual property protections, FAPEMIG provides approval of computer software, patents, and trademarks (national and international) divided into two fronts: institutional and independent. In the quadrennium, 50 brands, 176 patents, and 41 computer software's have been developed through the support of the foundation. These numbers are detailed in Table 10.

\section{Conclusions}

According to the indicator developed by the Economist Intelligence Unit (EIU) that analyzes 25 indicators in eight categories to form the ranking of the best places to invest, the State ranked third in General, being recognized as the third largest economy in Brazil, with positive indices of political stability, market growth, incentives for investment, provision of skilled labor and the promotion of research and development (EIU, 2011).

The prominent position reported is worth much to the growing performance of FAPEMIG in actions development ST\&I. The developing mining economy providing an increase in worker income, increasing their purchasing power, causes an increase in consumption levels. The state benefits from this growth (Increase in consumption levels) collecting more taxes, and the foundation too, because it gets $1 \%$ of this taxes. This sequence of facts allowed the foundation to increase the resources invested in 2011 to record fundraising.

The allocation of these resources during the quadrennium are mostly directed to research projects, provision of scholarships to aid research and training human resources, shares these priorities of the foundation. Both priorities observed positive growth, based on the first year of the quadrennium compared to others.

On the research projects, it was noted the latent concern foundation in follow projects funded, in order to verify that the desired results were achieved, justifying the expenditures made and providing subsidies for public managers to guide and refine the policies of science and technology.

It was noticed that the foundation held concern to cover its actions between higher education institutions in the State, looking for spraying among them the quotas available to researchers, avoiding concentrate resources, seeking joint development of these institutions.

Aiming to disseminate and share the knowledge generated by the projects and researchers, the foundation also listed in its priorities the promotion of scientific events, noting during the quadrennium increasing in a number of events promoted. In this same framework, the foundation through its researchers, concentrated efforts on the elaboration of scientific products, where in all of their natures, there was a plausible growth, highlighting the increase in publications of articles in scientific journals.

Not only looking for share, but also protecting the knowledge produced, the foundation created the intellectual property management, aiming at the advancement of intellectual property policy, recognizing the strategic importance for technological innovation in the State. 
In summary, the results make it possible to infer that the management of FAPEMIG happens in a structured way, realizing that the funds obtained for the actions of ST\&I follow normal levels in every year, showing that the foundation has clear strategies regarding the determination of priorities, which is recognized as fundamental for the scientific and technological development of Minas Gerais State.

\section{References}

Albuquerque, E. (1999). National systems of innovation and non-OECD countries: Notes about a tentative typology. Revista de Economia Política, 19(4), 35-52.

Barbosa, D. B. (2006). Law of Innovation: How to serve the productive sector (Lei de inovação: Como serve ao setor produtivo). Retrieved December 01, 2012, from http://denisbarbosa.addr.com/arquivos/200/inovacao/natura.pdf

Brazil. (2004). Federal Law $n^{\circ}$ 10.973/04 (Lei federal $n^{\circ}$ 10.973/04). Retrieved December 02, 2012, from http://www.planalto.gov.br/ccivil_03/_ato2004-2006/2004/lei/110.973.htm

Conselho Nacional das Fundações de Amparo à Pesquisa (CONFAP). (2012). The FAPs by Brazil (As FAPs pelo Brazil). Retrieved December 01, 2012, from http://www.confap.org.br/as-faps-pelo-Brazil/

Dosi, G. (1998). Sources, procedures and microeconomic effects of innovation. Journal of Economic Literature, 26, $1120-1171$.

Dzisah, J., \& Etzkowitz, H. (2009). Triple helix circulation: The heart of innovation and development. Proceedings from the Seventh Triple Helix Conference. Glasgow, Scotland.

Economist Intelligence Unit (EIU). (2011). Top management states Brazilians in 2011 (Ranking de gestão dos estados Brazileiros em 2011). Retrieved November 23, 2012, from http://veja.abril.com.br/infograficos/clp/levantamentos-e-metodologia.pdf

Etzkowitz, H., \& Leydesdorff, L. (2000). The dynamics of innovation: From national systems and Mode 2 to a triple helix of university-industry-government relations. Retrieved from http://www.chss.uqam.ca/Portals/0/docs/sts8020/(20)Etzk-Leides.Triple.Helix.pdf

Freeman, C. (1995). The national system of innovation in historical perspective. Cambridge Journal of Economics, 19, 5-24.

Fundação de Amparo à Pesquisa do Estado de Minas Gerais (FAPEMIG). (2008). Annual Report of Activities 2008 (Relatório Anual de Atividades de 2008) (pp. 1-64). Retrieved November 23, 2012, from http://www.fapemig.br/institucional/relatorio-de-atividades/

Fundação de Amparo à Pesquisa do Estado de Minas Gerais (FAPEMIG). (2009). Annual Report of Activities 2009 (Relatório Anual de Atividades de 2009) (pp. 1-89). Retrieved November 23, 2012, from http://www.fapemig.br/institucional/relatorio-de-atividades/

Fundação de Amparo à Pesquisa do Estado de Minas Gerais (FAPEMIG). (2010). Annual Report of Activities 2010 (Relatório Anual de Atividades de 2010) (pp. 1-95). Retrieved November 23, 2012, from http://www.fapemig.br/institucional/relatorio-de-atividades/

Fundação de Amparo à Pesquisa do Estado de Minas Gerais (FAPEMIG). (2011). Annual Report of Activities 2011 (Relatório Anual de Atividades de 2011) (pp. 1-104). Retrieved November 23, 2012, from http://www.fapemig.br/institucional/relatorio-de-atividades/

Maculan, A. M. (2005). Technological and innovation in Brazilian companies: Balance and perspectives (Capacitação tecnológica e inovação nas empresas Brazileiras: Balanço e perspectivas). Rio de Janeiro: FGV Cadernos EBAPE.BR.

Melo, P. (2005). The transfer of scientific and technological knowledge of the Federal University of Santa Catarina for the corporate segment (A transferência de conhecimentos científicos e tecnológicos da universidade federal de Santa Catarina para o segmento empresarial). Retrieved from http://producaoonline.org.br/rpo/article/view/352

Ministério da Educação (MEC). (2012). Supporting foundations: Presentation (Fundações de apoio: Apresentação) (p. 1). $\begin{array}{llll}\text { Retrieved December } & 6, & 2012, & \text { from }\end{array}$ http://portal.mec.gov.br/index.php?option=com_content\&view=article\&id=12508\&Itemid=1017

Organisation for Economic Co-operation and Development (OECD). (1999). Boosting innovation: The cluster approach. Paris: OECD.

Queiroz, F. C. B. P. (2007). University-business cooperation and adoption of innovations: A sector analysis of paints, varnishes and solvents and the university of the extreme south of Santa Catarina (Cooperação Universidade-Empresa E Adoção de Inovações: Uma Análise do Setor de Tintas, Vernizes e Solventes da Amrec e da Universidade do Extremo Sul Catarinense). Proceedings from the VII Coloquio Internacional Sobre Gestão Universitária da America do Sul. Mar del Plata (pp. 1-12). Argentina. 
Rapini, M. (2007). Interaction university-enterprise in Brazil: Evidence from the groups directory CNPq research (Interação Universidade-Empresa no Brazil: Evidências do diretório dos grupos de pesquisa do CNPq) (pp. 211-233). São Paulo: Estud. econ.

Rogers, E. M. (2003). Diffusion of innovations (5th ed.). New York: Free Press.

Simonini, A. (2010). Comparative study on the density of university-industry interaction in southern Brazil-2002/2008 (Estudo comparativo sobre a densidade de interação Universidade-Empresa na região sul do Brazil-2002/2008). Florianópolis: Monografia de conclusão de curso Economia.

Tidd, J., Bessant, J., \& Pavitt, K. (2001). Managing innovation: Integrating technological, market and organizational change (2nd ed.). Chichester: John Wiley \& Sons.

Zaltman, G., Duncan, R., \& Holbek, J. (1973). Innovations and organizations. New York: John Wiley. 